\title{
The Effect of Concept-Mapping on Secondary School Students' Performance in Islamic Studies
}

\author{
U.A. Ajidagba, Jamiu Abdur-Rafiu, Y.A. Fasasi ${ }^{a}$
}

\begin{abstract}
This study examined the effect of concept-mapping instructional method on secondary school students' performance in Islamic Studies in Oyo State, Nigeria. The study employed a pre-test, post-test control group, quasiexperimental design. The sample comprised Senior Secondary School class 2 (SSS 2) students purposively drawn from three secondary schools in Oyo State. The students in experimental and control groups were in their normal classroom setting (intact classes) and were not reorganized. Experimental group consisted of 45 students exposed to concept-mapping while the control group consisted of 48 students who received no treatment. Data were analysed using t-test, standard deviation and Analysis of Covariance (ANCOVA). Findings of the study showed that there was a significant difference in the performance of experimental and control groups after the treatment. Concept-mapping had significant effect on students' performance with mean score of $x=53.92$. Effect of Conventional method was $x=22.62$. No significant difference existed in the performance in Islamic Studies of students exposed to concept-mapping based on gender, t-cal. $(0.1469<2.021)$ at 0.05 alpha level of significance. The study concluded that concept-mapping instructional method positively improved students' understanding of Islamic Studies and invariably their performance. The study recommended that concept-mapping should be adopted as a teaching method of Islamic Studies, and that teachers of the subject should improve their pedagogical skills through seminars and workshops.
\end{abstract}

KEYWORDS: Concept-mapping, conventional method, Islamic Studies, secondary schools, students' performance, Oyo State.

a Department of Educational Management, University of Ilorin, Ilorin, Nigeria.Email: adefasas@yahoo.com 


\section{Introduction}

Concept-mapping is an instructional method that is employed in teaching of concepts in a classroom situation. It is a framework which contains either circles or boxes of the same type. Relationships between concepts are indicated by lines linking one concept to the other. Novak and Canas (2008) defined concept maps as graphical tools for organizing and representing knowledge. Also, Olorundare and Aderogba (2009) stated that concept-mapping involves mapping out and constructing logical relationships among concepts in a hierarchical order, such that the most general concepts are at the top of the map, while the most specific concepts are at the bottom of the map, and reflects the conceptual organization of a discipline. Thus, concept-mapping is a diagram indicating inter-relationship among concepts as representation of meaning or educational framework specific to a domain of knowledge (Okoye \& Okechukwu, 2010).COPYRIGHT 1999 Project Innovation. This material is published under license from the publisher through the Gale Group, Farmington Hills, Michigan. All inquiries regarding rights or concerns about this content should be directed to Customer Service.

Concept-mapping is also seen as a tool for assisting students to learn about the structure of knowledge and the process of knowledge production. It promotes meaningful learning by incorporating knowledge into cognitive structure using higher order thinking (Hassard, 2003). It is a strategy that students could find useful in understanding complex ideas and clarifying ambiguous relationships (Ajaja, 2011).

Concept-mapping, as an instructional method, is useful when an instruction is presented to learners in form of attributes and relationship among concepts. It could assist students in discriminating and associating with the context in which the concepts occur (Busari, 2001). In the same vein, Reiska and Ruohotie (2008), stated that as a graphical technique which represents ideas, it assists in thinking, solving problem, planning strategy and developing a process.

Moreover, this instructional method could assist students to brainstorm and generate new ideas, discover and integrate new concepts and communicate ideas clearly. (Inspiration Software Inc., 2016). As stated by Okebukola (1997) and Danmole (2004), the maps can be applied to any subject matter and at any level within the subject. This 
implies that concept mapping could be appropriate as a method for teaching Islamic Education.

Islamic Education, a process of physical, emotional, spiritual, social, economic and political development under the guidance of Holy Qur'an and Sunnah of Prophet Muhammad(Fasasi, 2002), became institutionalized when Prophet Muhammad received the first revelation of Qur' an in 610 A. D. According to the Sunnah of the Prophet, education is compulsory for all muslim males and females, young and old. Different methods of teaching and learning were adopted for knowledge and skills acquisition in the subject. Lubis, Yunus, Ishak, Muhamad and Diao (2010), examined five educational techniques and two educational strategies that were effective for teaching Islamic Education. They observed that many teachers of Islamic Education in West Africa encouraged their students to memorise lessons without understanding. They recommended the use of Information and Communication Technology (ICT) in teaching the subject. In the same vein, Khalediy (2011) reviewed Az-Zarnooji's book 'Instructing the learner: Methods of self learning'. The book stated that teacher-centred and pupil-centred methods, which included practice, application, repetition, dictation, memorization, dialogue and questioning techniques, were used by the $12^{\text {th }}$ century Islamic teachers. Khalediy concluded that these methods are still in use in the $21^{\text {st }}$ century. They are conventional methods commonly used by many teachers of Islamic Education in Nigeria.

\section{Statement of the Problem}

Despite the noticeable inputs of curriculum designers, policy makers and teachers towards design and implementation of Islamic Studies curriculum, reports show that students' performance in the subject in the recent years seems to be unattractive. For instance, reports from West African Examinations Council (WAEC) (2006), (2007) and (2008) show poor performance of many students in Islamic Studies in Nigerian secondary schools. Also, Oloyede (2012) analysed the percentage of examinees that had credit in Islamic Studies at Senior Secondary Certificate Examination (SSCE) between 1994 and 2012. His finding showed that the percentage of good performance was low. Incidentally, level of performance of students in any subject depends largely on the amount of learning that has taken place (Oladosu, 1986). This also depends on the use of relevant teaching methods. Thus, teaching 
methodology could influence a teacher's management of the teachinglearning process and the outcome of classroom interactions.

Studies such as Busari (2001), Adebayo (2006), Okoye and Okechukwu (2010) and Dambatta (2011), were conducted in an attempt to discover the relationship between different teaching methods and student learning. The studies focused on effects of instructional strategies on students' academic performance in science and social science subjects. However, there is still very little or no empirical research on effectiveness of concept-mapping in teaching Islamic studies. The researchers, therefore, focus on concept-mapping as a method of teaching Islamic studies in secondary schools.

\section{Purpose of the Study}

This study examined the effect of concept-mapping instructional method on secondary school students' academic performance in Islamic studies. Specifically, the study aimed at determining:

1. The difference in the performance in Islamic studies of secondary school students exposed to concept-mapping and conventional instructional methods.

2. The effect of gender on the performance of secondary school students taught Islamic studies using concept-mapping instructional method.

\section{Research Questions}

The following questions were raised and answered in this study:

1. Is there any difference in the performance in Islamic studies of secondary school students exposed to concept-mapping (CMP) and conventional (CONV) instructional methods?

2. What is the difference in the performance in Islamic studies of male and female students, exposed to concept-mapping and those exposed to conventional instructional methods?

\section{Research Hypotheses}

The following hypotheses were formulated and tested based on the research questions: 
$\mathrm{H}_{\mathrm{ol}}$ : There is no significant difference in the performance in Islamic studies students exposed to concept-mapping and those exposed to conventional method

$\mathrm{Ho}_{2}$ : There is no significant difference in the performance in Islamic studies of students exposed to concept-mapping instructional method based on gender.

\section{METHODOLOGY}

\section{Research Design}

The study employed a quasi-experimental design. It had the characteristics of non-randomized, non-equivalent, pre-test, post-test and control group. It was a $3 \times 2$ factorial design. The factorial levels were instructional methods using a conventional method (CM), conceptmapping (CM), crossed with students' scoring levels [low (L), Median (M) and high (H)] and students' gender [male and female]. The layout of the design is shown in Table 1.

Tables 1: A $3 \times 2$ Factorial Design

\begin{tabular}{llll}
\hline Independent Variables & Moderating Variables & $\begin{array}{l}\text { Dependent } \\
\text { ables }\end{array}$ & Vari- \\
\hline
\end{tabular}

Teaching Methods Gender/ Scoring Levels

Concept-mapping Male/ high; medium; low Performance in ISS

Female / high; medium; Performances in ISS low

Conventional Method Male/ high; medium; low Performances in ISS

Female / high; medium; Performances in ISS

low

\section{Population, Sample and Sampling Techniques}

The population for this study was all senior secondary school (SSS) students in Oyo State offering Islamic studies. The target population was SSS 2 students offering Islamic studies. The students in all the groups (Experimental and Control) were in their normal classroom setting (intact classes) and were not reorganized. Stratified, purposive, random sampling techniques were used. Experimental group consisted of 45 students exposed to Concept-Mapping, while the control group 
consisted of 48 students who received no treatment. The schools were selected from Ibarapa North Local Government Area (Oyo South), Ogbomosho South Local Government Area (Oyo Central) and Irepo Local Government Area (Oyo North) in Oyo State. The students were then stratified into the three different groups (low, average and high) by using the score of the previous term's Islamic Studies, English and Mathematics examinations to categorize them into high (Upper 70\% and above), average (Middle 45-59\%), and low (below 45\%) score groups.

\section{Instrumentation}

The instruments used in this study for data collection were divided into two:

1. Treatment instrument

2. Test instrument

The treatment instrument was a conventional and concept-mapping lesson plans on the topics treated. Test instrument was Islamic Studies Performance Test (ISPT). The ISPT contained 50 items multiple choice (objective questions) chosen from past SSCE questions of West African Examinations Council (WAEC) and National Examinations Council (NECO) (2008-2013). The Islamic Studies performance test had items on eight sub-topics; Shari'ah: definition and importance, Suratul Zalzalah (Meaning and commentary), Primary sources of Shari'ah, Revelation of Qur'an and its importance, Preservation of the Qur'an and its authenticity, Secondary sources of Shari'ah, Definition of Tafsir, and Scope of Shari'ah.

In addition, both the treatment instrument (lesson plans) and the test were validated. The reliability of the test items was obtained by administering the test items on an intact class of a non-participating school using test-retest in a time interval of three weeks. A reliability co-efficient of 0.76 was obtained.

\section{Procedure for Data Collection}

As a pre-test, the developed test instrument was administered on the subjects (in the experimental and control groups for the purpose of establishing equivalence about the knowledge of the subject matter among the groups) at the beginning of the study. The researcher and participating Islamic Studies teachers taught the selected topics to 
the Experimental and the control groups in the selected schools by employing concept-mapping and conventional methods respectively using 40 minutes lessons for four weeks.

Participants in the Experimental group were trained on the use of concept-mapping. Having mastered the use of the concept-mapping technique, the treatment then followed. This involved teaching the subtopics employing concept-mapping. After the treatment the post-test followed using the same test instrument used in the pre-test with items ordering re-arranged. Selected topics taught to the Experimental groups were taught to the subjects in the Control group using the conventional method without exposing them to the concept- mapping method. A post-test was administered on the subjects.

\section{Data Analysis Techniques}

The data collected were analysed using mean scores, standard deviation, t-test and Analysis of co-variance (ANCOVA) statistics. Specifically, research questions were answered using pre-test and post-test mean scores. ANCOVA was used to test the hypothesis 1 to establish whether the two treatments would significantly improve students' performance in Islamic Studies. Hypothesis 2 was tested using t-test and standard deviation statistics to establish whether students' gender would influence performance. A 0.05 level of probability was adopted as the criterion for determining significance.

\section{Data Analysis and Results}

The analyses were guided by the research questions and hypotheses formulated for the study

1. Is there any difference in the performance in Islamic studies of secondary school students exposed to concept-mapping (CMP) and conventional (CONV) methods?

Table 2: Pretest and Post- Test Mean Scores of the Performance of Islamic Studies Students Exposed to CMP and CONV. Methods of Teaching

\begin{tabular}{lllll}
\hline $\begin{array}{l}\text { Teaching } \\
\text { Methods }\end{array}$ & $\mathrm{N}$ & $\begin{array}{l}\text { Pre-test } \\
\text { mean }\end{array}$ & $\begin{array}{l}\text { Post-test } \\
\text { mean }\end{array}$ & Mean \\
\hline CMP & 45 & 10.46 & 64.38 & 53.92
\end{tabular}




\begin{tabular}{lllll} 
CONV. & 48 & 10.21 & 32.83 & 22.62 \\
Total & 93 & & & \\
\hline
\end{tabular}

From table 2, it was observed that the difference in the performance of students taught Islamic Studies using concept-mapping was 53.92 while the mean difference score of the control group is with the mean difference score of 22.62 .

2. What is the difference in the performance in Islamic stugly $\$ \Phi$ f male and female students, exposed to concept-mapping and those exposed to conventional method?

Table 3: Post test Mean Scores of the Performance in Islamic Studies of Male and Female Students Exposed to Concept-mapping (CMP) and Conventional (CONV) Methods of Teaching

\begin{tabular}{lllll}
\hline $\begin{array}{l}\text { Teaching } \\
\text { Method }\end{array}$ & $\mathrm{N}$ & Male & Female & $\begin{array}{l}\text { Mean Differ- } \\
\text { ence }\end{array}$ \\
\hline CMP & 45 & 61.38 & 63.25 & 1.87 \\
CONV & 48 & 42.60 & 34.74 & 7.86 \\
$\begin{array}{l}\text { Gender Mean } \\
\text { Difference }\end{array}$ & 18.78 & 28.51 & \\
\hline
\end{tabular}

From table 3, it was observed that the difference in the performance in Islamic Studies of male exposed to concept-mapping (CMP) and conventional methods was 18.75 while the mean difference score of female students was 28.51

\section{Hypotheses Testing}

The null hypotheses formulated for the study were tested and reported as follows.

$\mathrm{H}_{\mathrm{ol}}$ : There is no significant difference in the performance in Islamic studies students exposed to concept-mapping and those exposed to conventional method

Table 4: ANCOVA of the Performance of Islamic Studies Students Exposed to Concept- Mapping (CMP) (GD) and Conventional (CONV) Methods of Teaching 


\begin{tabular}{lllllll}
\hline Variance & $\begin{array}{l}\text { Sum of } \\
\text { squares }\end{array}$ & df & $\begin{array}{l}\text { Mean } \\
\text { Square }\end{array}$ & F. cal & F. crit & Decision \\
\hline $\begin{array}{l}\text { Between } \\
\text { Groups }\end{array}$ & 2.43 & 2 & 23.98 & 41.345 & 3.07 & S \\
$\begin{array}{l}\text { Within } \\
\text { Groups }\end{array}$ & 3140.6 & 131 & 0.58 & & & \\
Total & 3143.03 & 133 & & & & \\
\hline
\end{tabular}

$\mathrm{P}>0.05$

Since the critical $F$ value was 3.07 and the calculated value was 41.345 greater than F. critical value, the null hypothesis which says there is no significant difference in the performance in Islamic studies students exposed to concept-mapping and those exposed to conventional method is rejected. Therefore, there is a significant difference.

$\mathrm{Ho}_{2}$ : There is no significant difference in the performance in Islamic studies of students exposed to concept-mapping instructional method based on gender

Table 5: t-test Analysis of the Performance of Islamic Studies Students Exposed to Concept-Mapping (CMP) Based on Gender

\begin{tabular}{|c|c|c|c|c|c|c|c|c|}
\hline $\begin{array}{l}\text { Vari- } \\
\text { ables }\end{array}$ & $\mathrm{N}$ & $\mathrm{X}$ & $\mathrm{S}^{2}$ & $\mathrm{~S}$ & $\mathrm{df}$ & $\mathrm{t}$-cal & $\mathrm{t}$-crit & $\begin{array}{l}\text { Deci- } \\
\text { sion }\end{array}$ \\
\hline Male & 19 & 61.38 & 1583 & 39.81 & 43 & & & \\
\hline \multirow{2}{*}{$\begin{array}{l}\mathrm{Fe}- \\
\text { male }\end{array}$} & 22 & 63.23 & 1991 & 44.62 & 43 & & & \\
\hline & & & & & & 0.1469 & 2.0211 & NS \\
\hline Total & 41 & & & & & & & \\
\hline
\end{tabular}

$\mathrm{P}>0.05$

The t.cal. was 0.1469 while the t.critical value was 2.021 at $=0.05$. the t.cal. was less than t.critical at $=0.05$ Therefore, the null hypothesis which stated that "There is no significant difference in the performance in Islamic studies of students exposed to concept-mapping method based on gender" is hereby accepted. The result implies that there is no significant difference between post-test mean scores of male and female students. 


\section{Discussion of the Findings}

The result showed that there was a significant difference in the performance of students taught Islamic Studies using the conceptmapping instructional method when compared with the control group. The finding agrees with the findings of previous researchers like Adebayo (2006), AbdulSalam (2009), Olorundare and Aderogba (2009) and Dambatta (2011) who found in their respective studies that students that were exposed to concept-mapping perform better than those that were exposed to the traditional or conventional method. The effectiveness of concept-mapping could be attributed to its nature. As an instructional method, concept-mapping promotes meaningful learning. By this, students who employ meaningful learning are expected to integrate and retain knowledge over a long time and find new learning easier (Busari, 2001). This is contrary to conventional method which promotes rote learning. Although a student that employs rote learning will also retain information for a long time, he will have little or no integration of new knowledge and tends to quickly forget what he learns (Novak, 2001).

However, the use of concept-mapping instructional method did not produce any significant difference in the post-test mean scores of male and female students. Thus, gender has no influence on students' performance in Islamic Studies when concept-mapping is applied. The findings of this study disagree with the result of the study carried out by Abdur-Rafiu (2009) which recorded that gender has caused significant difference in the attitudes of male and female students towards learning Islamic Studies.

\section{Conclusion and Recommendations}

This study concluded that the Concept-Mapping instructional method positively improved students' understanding of Islamic Studies and invariably, their performance. Based on the findings in this study, it was recommended that in order to enhance students' performance in Islamic Studies, concept-mapping should be adopted as a teaching method. Islamic Studies teachers, who are the central factor at the Islamic Studies curriculum implementation level, should endeavour to improve on their pedagogical skills, broaden their knowledge of instructional methods, and constantly update their knowledge of innovations in teaching. There is need for constant organization of seminars and workshops for the Islamic Studies teachers on how the concept-mapping instructional 
method can be applied to the teaching of Islamic Studies. Curriculum and Educational Planners should incorporate innovative teaching methods with respect to Islamic Studies.

\section{References}

Abdul-Salam, A. (2009).Exposure to Concept-Mapping on students' performance in Social Studies' Environmental Education among post primary students in Ilorin, Nigeria. Ilorin Journal of Teacher Education, 5(1), 71-81

Abdur-Rafiu, J. (2009). Secondary school teachers and students' attitudes towards Arabic components of Islamic Studies curriculum in Irepo, Oyo State, Nigeria. Unpublished Masters Dissertation submitted to the Department of Arts and Social Science Education, University of Ilorin, Ilorin, Nigeria.

Adebayo, S. A, (2006). Effects of concept-mapping under three learning modes on senior school students' academic performance in chemistry in Ilorin, Nigeria. Unpublished Ph. D. Thesis, submitted to the Department of Science Education. University of Ilorin, Ilorin, Kwara State, Nigeria.

Ajaja O. P. (2011). Concept-mapping as a study skill: effects on students' achievement in Biology. International Journal of Science Education, $3(1), 49-57$

Al-Khaledi, K. (2011). Education and methods of teaching in Islam in the era of Az-zarnooji. Retrieved from www.qsm.ac.il/arblanguage/docs/majalla/ kalid

Busari, O. O. ( 2001). Comparative effects of four selected instructional strategies on students' achievement and retention in chemistry in some selected secondary schools in Lagos State. The College Review. A MultiDisciplinary Journal of Osun State College of Education, Ila -Orangun (8), 8-18.

Chebali, M. M. (2010). Concept-mapping as a teaching method to facilitate critical thinking in nursing education: A review of literature. Health $S A$ Gesondheld 15(1), 432-439. Available online www.hsag.co.za

Dambatta, B. U (2011). Effect of concept-mapping Instructional Strategy on Nigeria Certificate in Education Students' Performance in Trigonometry in Kano, Nigeria. Unpublished Masters Dissertation submitted to the Department of Science Education, University of Ilorin, Ilorin, Nigeria.

Danmole, B. T. (2004): Alternative Assessment Techniques of Students' Learning Outcomes. In I. O Abimbola, \& A. O. Abolade, (Eds). 
Fundamental Principles and Practice of Instruction. Ilorin: Department of Curriculum Studies and Educational Technology, University of Ilorin.

Fasasi, Y. A. (2002). Historical origin of education in Nigeria. Osogbo: POPAD publishers.

Hassard, J. (2003). Meaningful Learning Model. Retrieved from http://www. csudh.edu/dearhabermas/advorgbk02.htmv

Inspiration Software Inc. (2016). Teaching and learning with concept maps. Retrieved from www.inspiration.com

Lubis, M.A., Yunus, M. M., Ishak, N. M., Muhamad, T. A. \& Diao, M.(2010). The effectiveness of strategies and techniques in teacing and learning Islamic Education. Faculty of Education, Universiti Kebangsaan, Malaysia. Available on line http//ukm.pure.elsevier.com/en/publications/ the-effectiveness-of-srtategies-and-techniques...

Novak, J. D. (2001). IHMC Concept Map Software (Concept-mapping). Retrieved from http://ojni.org/602/strategies.htm

Novak, J. D. \& Canas, A. J (2008). The Theory Underlying Concept Maps and How to Construct and Use Them. Retrieved from http://www.stanford.edu/ dept/SUSE/projects/ireport/articles/concept_maps/The\%20Theory\%20 Underlying\%20Concept $\% 20$ Maps.pdf

Okebukola, P. A. (1997). The effect of concept-mapping on learner's metacognitive skills in problems solving. Available on line http://www.personal. psu.edu/wxh139/concept.htm

Okoye, N. S. \& Okechukwu, R. N. (2010). The effect of concept-mapping and problem solving teaching strategies on achievement in Biology among Nigerian secondary school students education; 131(2), 288. Retrieved from http:/www.highbeam.com/doc/1G1-251534602.html

Oladosu, A.G.A.S. (1986). What are learning theories? In A. Abdullahi \& N.A. Ihebuzor (Eds), Principles and practice of instruction . Ilorin: Department of Curriculum Studies and Educational Technology, University of Ilorin, Ilorin.

Olorundare, A. S. \& Aderogba, G. A. (2009). Comparative effects of conceptmapping, analogy and expository strategies on secondary school students' performance in chemistry in Ilesa, Nigeria. Journal of Curriculum and Instruction (JCI) 7(1\&2): 112-126

Oloyede I. O. (2012). Islamics: The conflux of disciplines. Being the One Hundred and Sixteenth (116th) Inaugural Lecture, University of Ilorin. Ilorin: Library and Publication Committee, University of Ilorin. 
Reiska, P. \& Ruohotie, P. (2008). Using concept mapping in vocational education. Proceedings of third international conference on concept mapping. A. J. Canas, P. Reiska, M. Ahlberg \& J. D. Novak (Eds.). Tallinn, Estonia \& Hesinki, Finland.

West African Examinations Council (2006). Executive Summary of Entries, Results and Chief examiners' Reports on the West African Senior School Certificate Examination (WASSCE) Conducted in Nigeria in 2006.

West African Examinations Council (2007). Chief examiners' Reports on the West African Senior School Certificate Examination (WASSCE) Conducted in Nigeria in 2007.

West African Examinations Council (2008). Chief examiners' Reports on the West African Senior School Certificate Examination (WASSCE) Conducted in Nigeria in 2008. 